IFAS Extension

\title{
Thousand Cankers Disease: A Threat to Black Walnut in Florida ${ }^{1}$
}

\author{
Don Spence and Jason A. Smith²
}

Thousand cankers disease (TCD) of walnut is a tree disease of the edible nut-producing and ornamental tree, black walnut (Juglans nigra) (Tisserat et al.). The first diseased trees were observed in New Mexico in the 1990s. The disease has since spread to most of the western states (Figure 1). Until 2009, diseased black walnut trees were only found outside of the natural range of black walnut, which occurs from the mid-Atlantic states to just west of the Mississippi River (USDA). In 2009, TCD was found near Knoxville, Tennessee; it has since spread to Pennsylvania and Virginia.

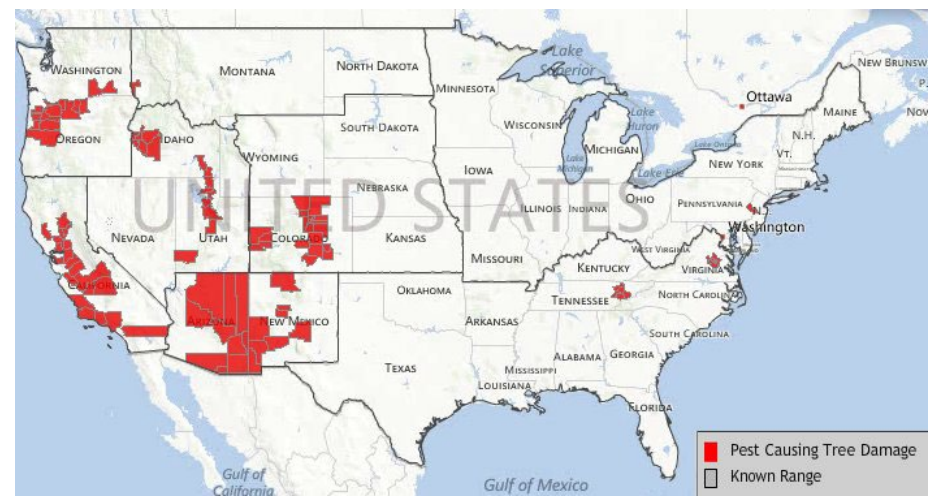

Figure 1. Thousand cankers disease has been reported in western and southwestern United States and in Tennessee, Virginia, and Pennsylvania. As the disease spreads eastward, it threatens eastern black walnut in its native range, which covers all or parts of over 30 states, including a portion of north Florida.

Credits: Image from USDA Forest Service, Forest Health Protection, 2011.

\section{Thousand Cankers Disease Biology}

The fungus that causes TCD was recently identified as Geosmithia morbida (Kolarik et al.), which is vectored by the walnut twig beetle (Pityophthorus juglandis) (Figure 2). This small bark beetle ( 1.5 to $1.9 \mathrm{~mm}$ ) is considered to be native to the southwestern USA; however, the native range of this newly reported fungus is not known (Tisserat et al.).

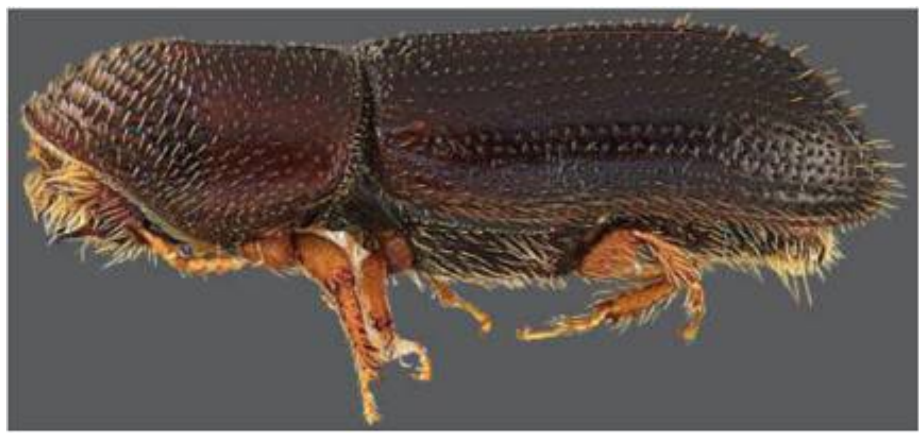

Figure 2. Walnut twig borer, Pityophthorus juglandis.

Credits: Purdue University Plant and Pest Diagnostic Laboratory.

The walnut twig beetle usually bores into the main trunk and branches of walnut trees (not twigs as the name would imply) and creates tunnels, called "galleries," just under the bark (Figure 3). In these galleries, females lay eggs and the developing larvae (red arrows) feed on wood tissue, causing further damage. The reproductive biology of the walnut twig beetle has not been fully established, but it is thought that both males and females create galleries, and they

1. This document is FOR308, one of a series of the School of Forest Resources and Conservation Department, Florida Cooperative Extension Service, Institute of Food and Agricultural Sciences, University of Florida. Original publication date February 2013. Visit the EDIS website at http://edis.ifas.ufl. edu.

2. Don Spence, adjunct professor of biology, Stetson University, DeLand, FL. 32720; and Jason A. Smith, assistant professor, School of Forest Resources and Conservation, Florida Cooperative Extension Service, Institute of Food and Agricultural Sciences, University of Florida, Gainesville, FL 32611. 
passively carry fungal spores on the outsides of their bodies into a host walnut tree. The fungal spores then colonize the wood of the walnut tree, causing cell death and lesions. The fungal activity, along with the activity of the beetle, girdles the tree and disrupt water flow from the tree's roots into the canopy (Colorado State University). This biology is different from that of ambrosia beetles, which bore into the centers of trees, usually have internal fungal spore-carrying sacs (mycangia), and feed solely on fungi.

Once the walnut twig beetle creates a gallery beneath the bark, the fungus grows and degrades the wood cells around the gallery. In these areas, necrotic lesions may coalesce, eventually inhibiting water and nutrient movement in the tree (Figure 3), and ultimately killing the tree. There are likely a variety of factors that influence the length of time it takes for black walnut trees to die. In Colorado, trees have died within two years of symptom development, and in other cases, trees with TCD symptoms have lived for over five years.

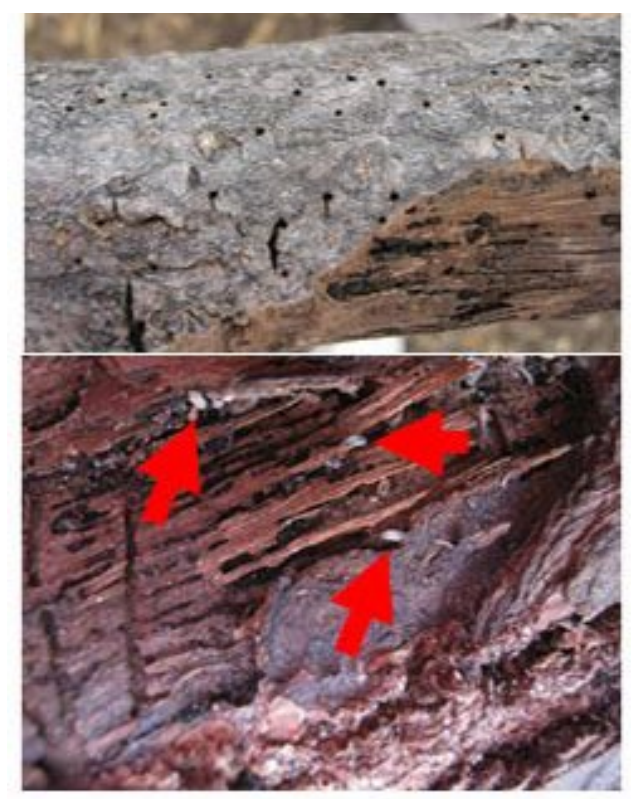

Figure 3. The walnut twig borer creates small bore holes (top) and then creates parallel galleries (bottom) beneath the bark where the female lays eggs that develop into larvae (red arrows).

Credits: D. Spence.

\section{Potential Spread of TCD}

The natural range of black walnut is from just west of the Mississippi River, throughout the Midwest, New England, down the Atlantic coast, and into northwest Florida. The counties in Florida where black walnut is likely to occur are Holmes, Jackson, Washington, Bay, Jefferson, Calhoun, Gadsden, Leon, and Liberty Counties. Within each of these counties, black walnut trees are likely to be uncommon because the species is at the southern edge of its natural range. However, black walnut trees have been planted ornamentally throughout central and north Florida, creating the potential for extensive damage to urban black walnuts in Florida.

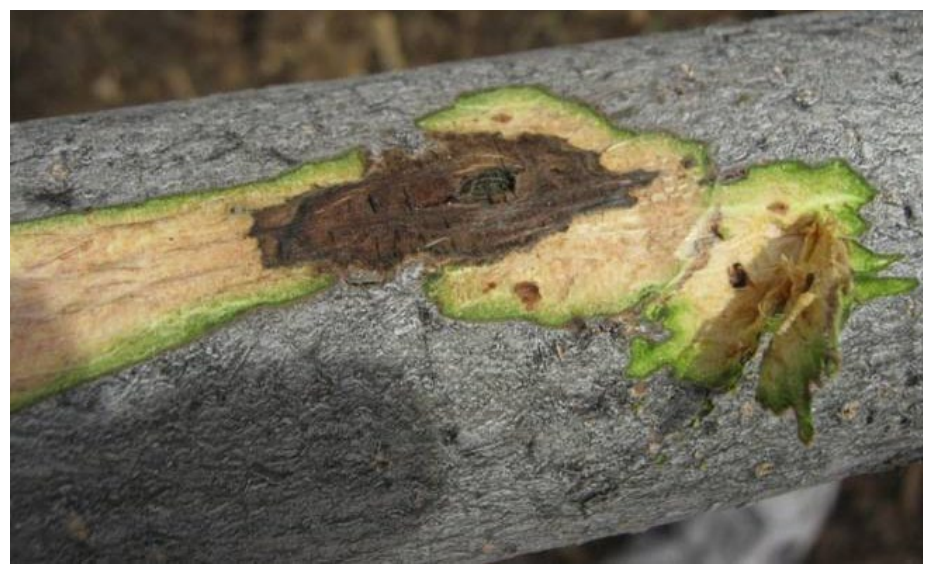

Figure 4. Lesion caused by the pathogenic fungus, Geosmithia morbida. The dark area is necrotic tissue (dead wood). At the center of the lesion is a hole where the walnut twig borer entered.

Credits: Photo by D. Spence.

\section{How to Tell If Your Black Walnut Tree Has TCD}

Black walnut trees that have been attacked by the walnut twig borer carrying the pathogenic fungus are likely to develop the following symptoms (Figure 5):

- Thinning canopy

- Yellowing leaves

- Leaf wilt

- Branch tip dieback

- Presence of brown to black necrotic areas under the bark in areas of small bore holes.

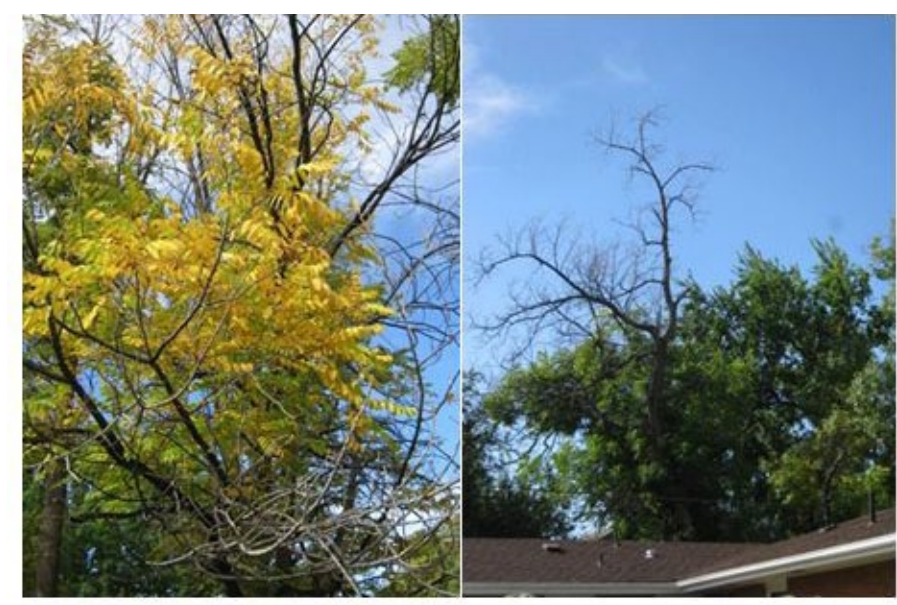

Figure 5. Left: Yellowing or chlorosis, caused by TCD. Right: An entire portion of the canopy of this black walnut tree in Boulder, $\mathrm{CO}$, has been killed by TCD Credits: D. Spence. 


\section{Management of TCD}

So far, there is no way to prevent the insect or fungus from entering a black walnut tree. The beetles are so small that it is not feasible to spray insecticides to eradicate them. One possible method to keep trees alive is to use fungicide injections before the trees are attacked. This method has been used against laurel wilt, Dutch elm disease and tree decline caused by the mountain pine beetle. Black walnut produces a fruit (the walnut) that can be eaten by humans and animals. Due to this, the U.S. Environmental Protection Agency has not yet approved a fungicide for use on walnut.

Initiatives are underway to identify individual black walnut trees that are resistant to the pathogenic fungus. To protect non-infected trees, some communities in Colorado have initiated an aggressive program of removing diseased trees. This method of sanitation has proven successful in some communities where Dutch elm disease and the emerald ash borer occur in the Midwest and holds promise for management of TCD.

Just recently, the states of Kansas, Missouri, Michigan, and Nebraska have all imposed quarantines on the movement of non-treated or unfinished walnut wood products. The penalty for moving walnut into quarantine areas can result in fines. The fear is that people will move infested black walnut wood and subsequently move TCD to new areas.

\section{What You Can Do If You Think You Have TCD}

Black walnut trees that have the symptoms listed above should be examined by a qualified arborist or forest pathologist for positive identification. Contact your county Extension agent if you suspect TCD in your walnut trees. Trees that are found to have TCD should be immediately cut down and disposed of by burning, chipping, or be taken to a landfill to be buried.

At no time should dead walnut trees, wood or logs be saved for wood working or be moved without being kiln dried to a temperature of at least $70^{\circ}$ Celsius.

At no time should any non-treated logs or firewood be moved a distance of more than 50 miles. In Florida, a ban on the movement of untreated forest products (fire wood for instance) was enacted in August 2010.

\section{How likely Is TCD to Arrive in Florida?}

It is very likely. Since the disease has spread to Pennsylvania and Virginia from Tennessee, it is possible that within the next decade TCD could naturally spread to Florida. However, if people continue to move TCD infested walnut logs from place to place, this disease could arrive in Florida tomorrow.

\section{References:}

Colorado State University Department of Bioagricultural Sciences and Pest Management, Thousand Cankers Disease / Walnut Twig Beetle webpage http://www.colostate.edu/ Dept/bspm/extension\%20and\%20outreach/thousand\%20 cankers.html

Kolarik, M., E. Feeland, C. Utley and N. Tisserat. 2011. Geosmithia morbida sp. nov., a new phytopathogenic species living in symbiosis with the walnut twig beetle (Pityophthorus juglandis) on Juglans in USA. Mycologia, 103(2): 325-332.

Tisserat, N., Cranshaw, W., Leatherman, D., Utley, C., and Alexander, K. 2009. Black walnut mortality in Colorado caused by the walnut twig beetle and thousand cankers disease. Online. Plant Health Progress doi:10.1094/ PHP-2009-0811-01-RS.

USDA Forest Service, Northeastern Area http://www.na.fs. fed.us/pubs/silvics_manual/volume_2/juglans/nigra.htm

Additional Links:

U.S. Forest Service, National Forest Health Monitoring

http://www.fs.fed.us/foresthealth/fhm/sp/tcd/tcd.shtml

USDA National Invasive Species Information Center

http://www.invasivespeciesinfo.gov/microbes/thousandcankers.shtml\#org 